\title{
Islamic mutual funds as faith-based funds in a socially responsible context
}

\author{
G. Forte and F. Miglietta \\ Bocconi University, Milan
}

\begin{abstract}
Defining social investing and its boundaries is a challenging task. Since the religious beginning of ethical investments, many overlapping investment styles have been grouped into the bucket of socially responsible investments, or SRI. This includes, for instance, faith-based investments. In this paper we study the underlying principles of SRI and Islamic funds as investment classes, and try to determine whether Islamic mutual funds, as faith-based investments, can be included into the category of socially responsible mutual funds, or if they exhibit distinguishing characteristics that indicate that they would be more fittingly grouped in a separate investment family. We address the question from both a qualitative and quantitative point of view. Comparing ideas, ratios and investment styles underlying SRI and comparing them to Islamic portfolios, we identify the potential inconsistencies related to some of the investment decisions. Together with a qualitative assessment of the differences and similarities, we discuss, in the quantitative section of our study, the different sector and country composition of two generic portfolios, SRI and Islamic (proxied by relevant European indices), derived from the application of the investment screens. In addition, through a cointegration analysis on FTSE indices, we show that FTSE Islamic, exhibits peculiar and interesting portfolios' differences in terms of econometric profile, compared to conventional and SRI indices. This paper attempts to unify the studies regarding SRI, with the available studies on Islamic investments. To the best of authors' knowledge, this is the first time that SRI and Islamic indices are analysed and compared.
\end{abstract}

JEL Classification : G12, G14

Key words: Style Analysis, Ethical Investments, Socially Responsible Investments, Cointegration Analysis, Islamic Investments, Islamic Mutual Funds 


\section{Introduction}

Socially responsible investing (SRI) has grown substantially the last two decades, mirroring the public's concern with environmental and social issues. The development of ethically screened investments emerged in the $1970 \mathrm{~s}$ as a demand-driven response. Initially, just a few investors, concerned with screening out armaments and "sinful" stocks, invested in the Pax World Fund and the Friends Provident Stewardship.

In Europe, SRI assets under management total about 1.15 billion Euros, comprising $10-15 \%$ of all managed assets. Approximately $94 \%$ of these assets belong to institutional investors, mainly charities, pension funds and churches (e.g. Methodists, Quakers, Presbyterians and Anglicans) (Eurosif, 2006). SRI is also growing in importance in the US, where it makes up about 2.29 billion dollars, or 9,4\% of total managed assets (Social Investment Forum, 2005).

Islamic investors, as Wilson (1997) points out, may be interested in different screening criteria but the idea of excluding companies according to a set of ethical constraints is of mutual interest. The guidelines of Islamic investments are based on tawhid - a total adherence to the willing of God - revealed to the world by the words of the Prophet Mohammed (Mills and Presley, 1999). A hadith attributed to the Prophet states that "every loan that attracts a benefit is riba (usury)", and for this reason Islam prohibits the charging of interest. Furthermore, since uncertainty (gharar) and gambling (maisir) are prohibited, any observant Muslim has to carefully deal with financial contracts.

The investors entering the Shari'ah compliant investments, and in particular, the Islamic mutual funds, are increasing about $12-15 \%$ per year, and the total equity assets under management have reached a total of $\$ 16$ billion (Smyth, 2006; Failaka 2007).

To introduce morals, religion and conscience into investments is a challenging task and a difficult problem to overcome. Business ethics scholars are unable to precisely define social investing, and attempts to identify what falls within the ambit of social investing can lead to different answers (Dunfee, 2003). Furthermore, when speaking of socially responsible, moral, and faith-based funds, are we dealing with the same class of investments or we are grouping investment styles without overlap and with characteristics that are mutually inconsistent? In this paper, we address this question through both qualitative and quantitative approaches.

In the qualitative exercise we concentrate on the analysis of the main investment strategies applied in the screened portfolios (Socially Responsible and Islamic), and discuss fund management issues. Concentrating on similarities and differences between SR and Islamic Funds, and basing our considerations on an ideal archetype of SR fund, we come to the conclusion that Islamic investments, as faith-based investments, should be excluded from the general grouping of SRI.

Moreover, we discuss the similarities and differences also in quantitative terms. In the quantitative part of our study, we demonstrate the differences in the sector and country composition of two generic portfolios, SRI and Islamic (proxied by relevant European indices), deriving from the application of the investment screens. In addition, through a cointegration analysis of FTSE indices, we show that FTSE Islamic is cointegrated with interest rates and exhibits peculiar and interesting portfolios' differences in terms of econometric profile, compared to conventional and SRI FTSE indices.

This paper attempts to unify the studies regarding SRI (Cooper and Schlegenmilch, 1993; Cowton, 1994; Benson et al., 2006; Hellsten and Mallin, 2006) and their performance (Hamilton et al., 1993; Orlitzky et al., 2003), with the available studies on Islamic investments (Usmani, 2002; Elgari, 2002; Naughton and Naughton, 2006). Some authors have analysed the characteristics of Islamic indexes (Girard and Kassan, 2005; Hakim and Rashidian, 2004), comparing them to conventional indices (but not with the SR counterparts). To the best of authors' knowledge, this is the first time that SRI and Islamic indices are analysed and compared. 


\section{Fundamentals of SRI}

SRI have undergone quick development in Europe in the last few years. The movement was originally born during the 1920s in the UK when the Methodist Church began avoiding "sinful stocks" in its investment policy. By the $1960 \mathrm{~s}$, this financial-moralist movement had started to spread to the rest of Europe, as churches and religious groups attempted to place their financial investments in line with their views and principles. In 1971, pushed by the United Methodist Church and in response to ethical concerns about armaments, the Pax World Fund was born. Later, in 1984, Friends Provident, an old mutual insurance company founded by The Society of Friends (commonly known as the Quakers), launched the Friend Provident Stewardship.

At the beginning, deriving from religious schemes, screened investments were defined as "ethical" since, in a religious sense, the term is associated with a precise set of norms. The terms "ethical investments" and "socially responsible investments" are often used interchangeably; the former is widely used in some parts of the world (typically the UK, Canada and Australia), and the latter term in other parts, such as in the States (Hellsten and Mallin, 2006).

Cowton (1994) defines ethical investments as those that make use of ethical and social criteria in the selection and management of investment portfolios. Using this as a basis, many authors have tried to establish a comprehensive definition; however, this is not a simple task and business ethicists have not reached a general consensus. The world of ethical investments and definitions associated with it can be greatly influenced by the cultures of various countries. While religious criteria were originally used, they have been supplanted at times by environmental strategies, antiwar projects and human rights activism (Sparkes, 2002).

Eurosif (the European Social Investment Forum) states that "socially responsible investments combine investors' financial objectives with their concerns about social, environmental and ethical (SEE) issues". The acronym used - SEE - can be enriched by adding corporate governance issues, thus becoming environmental, social and governance (ESG). In both cases, emphasis is placed on financial performance in accordance with the so-called "triple bottom line", commonly known as the "three P's rule: people, planet and profit".

The definition provided by the North American Social Investment Forum is only slightly different, stating that "socially responsible investing (SRI) is an investment process that considers the social and environmental consequences of investments, both positive and negative, within the context of rigorous financial analysis" (Social Investment Forum, 2005). In both of the above definitions, the emphasis on financial performances is obvious - there is not social investment without financial soundness. Even if, in theory, an investor is willing to sacrifice some part of performance to reach social goals that he considers very important, the performance of ethical funds is very much of concern as in the case of any other financial investment (Wilson, 1997).

According to these ideas, SRI's investment ratio can be summarized as follows:

1) A moral duty exists and it is related to sustainable development. As suggested in the Brundtland Commission's report, "Our Common Future" (1987), development should be handled such that it meets the needs of the present without compromising the ability of future generations to meet their own needs;

2) SRI can represent a positive economic value added, in terms of company performance. Indeed, SR companies are less subject to potentially damaging legal controversies linked to environmental pollution, human rights charges, and illegal work practices. Virtuous companies avoid corporate scandals and reputation losses. Implementing a code of conduct and socially responsible practices may incur costs in the short run, but could be offset in the long run through higher reputation and avoiding unexpected legal costs. 
Orlitzky et al. (2003) confirm this insight. They provide an analysis of all previous literature on the topic, concentrating on the relationship between corporate social or environmental performance and corporate financial performance. Their findings suggest that corporate virtue, measured by social responsibility and, to a lesser extent, environmental responsibility, is likely to pay off in a better reputation.

Of course, an SR portfolio can be composed in several manners and asset managers have, from time to time, used different strategies, detailed in Table 1.

\section{[ Insert Table 1 about here ]}

In their infancy stage, SR portfolios were chosen according to negative criteria (ethical exclusion, simple screen/simple exclusion). "Black" sectors and stocks were excluded from the portfolio menu.

At present, the best-in-class strategy is largely used in Continental Europe, while the ethical exclusion strategy is very popular in the UK and among Danish pension funds. In contrast to Europe, in the United States and in Canada, concerned investors promote shareholder advocacy, allowing investors to file and vote shareholder resolutions focused on social and environmental concerns.

Many funds refer, in their asset management process, to socially responsible indices, composed of a set of securities created according to clear, pre-defined criteria. There are a number of highly diversified screened indices investing in different asset classes. This is the case, for instance, with Dow Jones Stoxx Sustainable Indices, the Domini Social Indices or FTSE4 Good. To create an SR index, researchers select stocks from a wide universe conventional indices, and apply criteria related to social behaviours, environmentally friendly projects and practices, human rights and workers' rights. ${ }^{1}$ Furthermore, particular attention to negative criteria is focused on some "countries of concern", where human rights are frequently violated; Angola, Egypt, Iran, Saudi Arabia, Syria, Zimbabwe are on the watch list.

According to the most recent research on the European SR market, there are now at least 388 open-end mutual funds in Europe. These open-end funds primarily invest in equities (Avanzi, 2006). The assets under management in Europe are estimated at about 34 billion Euros, and the leading countries - the UK, France, Sweden and Belgium - account for more than $60 \%$ of the total.

In the US, the size of screened mutual funds is larger, totalling 180 billion US dollars in investments, even though the number of mutual funds in the US is smaller than in Europe (201 funds at the end of 2005).

\section{Fundamentals of Islamic investing}

Islamic law and precepts constitute a part of every Muslim's cultural and spiritual identity (DeLorenzo, 2002). These laws are based largely on the Qur'an and the Sunnah, which is the practice of the Prophet. To use the wording of Usmani (2002), "the divine revelations are to be followed in letter and spirit and cannot be violated or ignored on the basis of one's rational arguments or his inner desires".

The Holy Qur'an does not contain only moral teachings, but offers guidance in all aspects of life, including any socio-economic behaviour. This should not be surprising; the Prophet was a successful business man, known for his integrity and honesty. In his teachings he regulates family behaviours and inheritance, contracts and property, social and fiscal norms, and the use of public and private goods. These prescriptions are to be intended as imperatives for every man. The religion 
is a fusion of temporal and spiritual aspects of life (Elfakhani and Hassan, 2005). Islam is, then, a modus vivendi - a lifestyle (Abbasi et. al., 1989), and differs from the other two monotheistic religions - Christianity and Judaism - because no division can be made between the State and the religion itself (Baldwin, 1990).

Islamic economy is founded on Shari'ah: it does not deny profit, private ownership and market forces, but they are not given total freedom and must be reached in accordance with the divine prescriptions.

In term of major macroeconomic goals, Islamic economy tends to achieve full employment, a positive economic growth rate and a stable value of the money (Chapra, 1985). A "just" rate of profit is admissible and must derive from one's own work (Mills and Presley, 1999). No reward can be obtained without strength and honest effort, and working represents a moral duty. The benefits of health and development are meant to reach Islamic society as a whole, the Ummah. Everyday business conduct must be characterized by honesty and bona fides, and the contracts are always to be honoured (DeLorenzo, 2002).

Money is only a mean of exchange; it cannot be used as an asset and may not generate a profit. At the same time it cannot be left unproductive, thus hoarding is not allowed under the Shari'ah law. Money must always be associated to some real transaction, and this is why Islamic economy is considered an asset-backed economic system. Charging interest on money loaned (riba), regardless of the rate imposed, is explicitly prohibited. Riba encompasses every form of exploitation in business conduct and the concept is not strictly related to charging interest (Naughton and Naughton, 2000). In the Qur'an it is stated that "those who devour usury will not stand except as stand one whom the Evil one by his touch Hath driven to madness. That is because they say: -trade is like usury-, but Allah hath permitted trade and forbidden usury" (II, 275-283). Furthermore, "that which ye give in usury in order that it may increase on (other) people's property hath no increase with Allah; but that which ye give in charity, seeking Allah's Countenance, hath increase manifold" (XXX, 39).

The riba condemnation has an historical root: during the Prophet times, when the matured debt was not paid back, the amount due to the creditor was doubled (Saleh, 1986). Condemning riba as leading to restless curse and madness, the Prophet instead advocated to share the risk associated to any lawful business, since "profit comes with liability". This prescription forms the basis for the profit and loss sharing economic scheme, and indicates that one only becomes entitled to profit when one shares the risk of loss. To do otherwise, one would be considered an economic parasite and a sinner (Archer and Karim, 2002; Nyazee, 1998).

Another of the basic elements of the Islamic finance is related to the prohibition of risk and uncertainty: any sort of ambiguity in contracting is referred to as gharar and it is prohibited. Any uncertainty as to the quantity, quality, deliverability or existence of the asset to be traded will be prohibited (Fadeel, 2002). The concept of maisir, or any gambling activity, is related to gharar.

All the prohibitions combined together have the ultimate and cumulative affect of preserving balance, distributive justice and equality of opportunities and must be always honoured in any transaction that must be regarded as an Islamic one ${ }^{2}$.

\section{Islamic mutual funds industry}

Beginning in the 1980s, the most prominent Islamic institutions have started to widen the coverage of financial instruments, to serve the more sophisticated financial needs of the high net worth individuals living in the Gulf area. In addition to the demand deposits and the basic current accounts, the Islamic intermediaries started to implement collective investment schemes, through special purpose vehicles intended to manage the savings of the customers, in line with the Shari'ah law. The Islamic assets management instruments were born as the answer to this need. Although 
these funds are still in their infancy, they have the potential to play a pivotal role in financial markets, since Muslims constitute about 20\% of the world population (Girard and Hassan, 2005).

Islamic funds have experienced a dramatic growth during the second half of the 90s; the equity Shari'ah compliant investments have increased from fewer than 10 funds to 218 , and are being managed by primary investment houses that manage a total of $\$ 16$ billion in assets (Failaka, 2007). The economic reasons behind this increase can be explained by the extreme growth of the Gulf Cooperation Countries stock markets, led, in particular, by Saudi Arabia (Smyth, 2006). In the 80s, the Saudi Commercial Bank and the National Commercial Bank pioneered these collective investment schemes. At first, these financial institutions established joint ventures with the most experienced Western investment houses that provided the skills to structure and manage Islamic mutual funds (Cox, 2007). Many primary Western investment houses, like UBS, Schroders, HSBC, and Deutsche Bank, are now managing Shari'ah compliant mutual funds and are also trying to attract Muslim retail investors who want to screen their investments according to their religious beliefs.

The most common contract structure for Islamic funds is linked to the Profit and Loss Sharingbased (PLS) mudarabah. The capital provider (the investors), called rabb-ul-mal, entrusts the asset manager, called mudarib, to take care of the business, using his expertise and skills. The manager's efforts will be remunerated by a share in the profits, according to agreed upon ratios. If the business is not successful, the whole capital loss will be suffered by the rabb-ul-mal, unless the loss has been caused by the misconduct, negligence, or if the manager did not act according to bona fides or ultra vires (Fadeel, 2002).

Before detailing the investment process, it is important to acknowledge that, to be valid under the Shari'ah law, investments must abide by two basic conditions (Usmani, 2002). The first is related to the PLS the investors enter into when delegating their investment choices to fund managers. No fixed return can be promised or obtained; the profit is strictly linked to the performance of the companies whose stocks are in the portfolios. The second binding condition is referred to the inclusion in the portfolios of Shari'ah's acceptable securities.

Ideally, we can split the investment process into three distinct phases, all ruled by the religious prescriptions: 1) portfolio asset allocation, 2) instruments and trading strategies and 3) income distribution and purification.

\section{1) Portfolio asset allocation}

As in the case of socially responsible funds, the starting menu of stocks is to be screened according to the religious prescriptions. The manager has to set up qualitative and quantitative criteria to ensure the compliance of the final portfolio.

The qualitative screens to be applied relate to the main activity of the company and to the way in which the company is financed or invests its liquid assets. Stock investment decisions are not a simple task since, according to Moore (1997), "strictu sensu, basing on most rigorous Shari'ah interpretation, all stocks are virtually off-limits".

All the main activities of the company must be halal - all banks and insurance companies whose activity is interest-based are to be screened out as well as all companies involved in alcohol, tobacco and armaments manufacturing and trading, or involved in entertainment businesses. ${ }^{3}$ Moreover, if the business is halal but the company borrows money on interest, or deposits its surpluses into interest-bearing accounts, the shareholders' have the moral duty to file resolutions in the general assembly to publicly condemn this behaviour (Usmani, 2002). This is similar to the shareholder activism in the SR case. 
After applying these qualitative filters, all remaining stocks are to be analysed on the basis of quantitative screens related to debt, interest-bearing securities and receivables and cash. According to Elgari (2002), the total outstanding debt must not exceed one-third of the capital and the same rule applies to cash and interest-bearing securities of the assets. The threshold of $33 \%$ derives directly from the words of the Prophet, who states that "judgment is based on majority, not on minority", and "the dividing line between a majority and minority is one third, and the third as a portion is considered to be much". So, from the interpretation of these two maxims, the scholars derive that income from non-permissible sources should account for less than $33 \%$.

The stress placed on debt, interest-bearing securities and receivables clearly stems from the avoidance of riba. The prohibition of hoarding, instead, is the basis for the condemnation of holding excessive cash.

For interest-based companies, according to the more orthodox interpretation, to invest in companies involved in riba does mean a silent acceptance of these unlawful practices. Because of this assumption, all such companies are to be screened out. However, some experts do not endorse this stringent view, arguing that a stock company is different from a simple partnership since all decisions are to be approved during the assembly through majority. ${ }^{4}$

\section{2) Instruments and trading strategies}

Once it is decided which companies can be included in the portfolio, the fund manager must comply with the rules related to the portfolio management activity. Since there is no clear Shari'ah guidance as to their acceptability, instruments such as shares, bonds, futures, options, and swaps can create problems in portfolio management. Following the interpretation given by the Islamic Fiqh Academy of Organization of Islamic Countries, representing one of the primary authorities in the interpretation of Islamic law, it is possible to identify the problems that arise using such instruments and the correct modus operandi in an Islamic context.

In terms of bonds, the certificate itself is evidence of a lender-creditor relationship and it is clear that in the conventional system of bond issuance and trading, interest is at the centre of any transaction, in violation of the general prohibition of usury in the Islamic financial system (AlAmine, Al-Bashir, 2001). However, it is possible to overcome the problems associated with the prohibition on charging interest, and some innovative structures have been developed to allow greater freedom for investors.

If the company's business is legitimate, and its conduct is in compliance with the rules of Shari'ah, Muslims are allowed to own compliant common stocks. Common stocks were approved as an instrument for investment by the Council of the Islamic Fiqh Academy in 1993. The same is not valid for preferred stock. While there are several ways in which common and preferred stocks differ, the most significant way, from an Islamic legal point of view, is that preferred stocks guarantee the amount of the dividend. Such a predetermined and guaranteed rate of return is prohibited for the reason that it may be classified as riba. So, as a general rule, Muslim investors may trade only in common stock.

Common stocks are a legitimate form of investment in Islam, but many of the practices associated with stock trading are not halal (permitted). Short selling and margin trading, for instance, are severely restricted. The prohibition of borrowing to invest (margin trading) is based on the prohibition of riba, whilst short selling involves huge risk with almost no upper limit. Moreover, from the Shari'ah point of view: "you cannot sell what you do not posses".

Some important additional considerations are related to derivatives, such as stock futures and options. In spot or cash transactions, both commodity and money are exchanged simultaneously and immediately. In the deferred transaction, the commodity is delivered but money payment is 
deferred. Salam is the only halal form of deferred delivery - money is paid on the spot but the commodity will be delivered at a future date.

Futures transactions, in which delivery of both money and commodity are to take place at a future date, it is not an accepted dealing. Moreover, as argued by Chapra (1985b), all forms of modern futures contracts do not result in an exchange of the title of the underlying commodity, and without a clearly defined commodity, the ability to physically deliver anything is in doubt. ${ }^{5}$

As for options contracts, a number of scholars have found such contracts objectionable, but ultimately Kamali (1997) concluded that "there is nothing inherently objectionable in granting an option, exercising it over a period of time or charging a fee for it, and that options trading like other varieties of trade is permissible and as such it is simply and extension of the basic liberty that the Quran has granted".

\section{3) Income distribution and purification}

When included in portfolios, partially "riba contaminated" balance figures are to be cleansed or purified. Once managers have identified what is not acceptable from a Shari'ah point of view, they should deduct from the returns the haram (prohibited) part of the earning. This purification process is done either by the fund manager before any distribution of income, or by reporting the necessary financial ratios for investors to purify their earnings on their own. This choice is summed up in the "deduct or inform" dilemma. In the first case (deduct), the manager distributes to the investor a "net" (purified) profit. The second option, instead, is more practicable: the fund manager informs the investor and advises the part to be purified. In this case, the manager can also indicate to the Muslim investor the part that is subject to Zakah, a religious form of charity that all wealthy people must pay on personal wealth every lunar year (Ahmed, 2002). Under a return and market appeal point of view, if no deduction is made from the net asset value of the portfolio, the fund appears more profitable and can also be sold to non-Islamic investors. Such non-Islamic investors would conversely be penalised by the "deduct" option.

\section{The Shari'ah boards}

Shari'ah Board supervision is fundamental in structuring any of the Islamic instruments that are issued on financial markets. In managing Islamic funds, the Board has the twofold role to certify the compliance of any stock traded to Shari'ah law and to ensure that the portfolio is able to create value for the shareholders.

Despite the increasing importance of this role, there is no general consensus regarding some specific elements of the Board. Different ideas exist about the role of the Board, how it functions, and its legal status. According to some, the legal opinion (fatwas) issued by the Board are binding for the managers. According to others, they are just important opinions ${ }^{6}$.

The Accounting and Auditing Organization for Islamic Financial Institution (AAOIFI) recently introduced a Standard for the board composition. According to AAOIFI (2005),

"a Shari'ah Supervisory Board is an independent body of specialised jurists in fiqh almu'amalat (Islamic commercial jurisprudence)... it may include a member who should be an expert in the field of Islamic financial institutions and with knowledge of figh almu'amalat. The Shari'ah supervisory board is entrusted with the duty of directing, reviewing and supervising the activities of the Islamic financial institution ... The fatwas and ruling of the Board shall be binding".

From a practical point of view, the main difficulties in interpretation are linked to the different jurisprudential schools to which the Shari'ah experts belong to. These schools' point of views differ 
on ijtihad, the correct ruling on a given issue, regarding the legal interpretation of Qur'an and Sunnah. The four major Sunni "schools of law or jurisprudence" (madh'hab) are the Maliki, Hanafi, Sha'fi'i, and Hanbali. Their ideas could differ on some points.

Those funds not willing to establish a Shari'ah Board can delegate all the relevant decisions to the Islamic Indices that provide a Shari'ah compliant menu of stocks already screened by eminent scholars.

\section{Some critical points on Islamic mutual fund management}

Some scholars have offered their views on interest and hoarding outside the context of mutual fund stock picking. According to some pragmatic experts, cited in Moore, (1997) even though riba and investments on the basis of interest are severely prohibited, a similar prohibition applies to hoarding and unproductive money accumulation. For this reason it is important to find an acceptable compromise.

A compromise can also be necessary in the case of Western banks acting as capital providers. Indeed, Islamic financial intermediaries are not as capitalised to allow Islamic companies to avoid Western banks (who act on the basis of riba). Similarly, Islamic stock markets, which are still growing, cannot entirely provide the capital needed for development. As a whole, Islamic economy is characterized by inefficient liquidity management; there is not yet an interbank market and an effective lender of last resort is not still in place (Maroun, 2002; Husain, 2002).

The stock market development is directly linked to the access to market by small investors. This participation, though desirable, is not yet perfectly in place. Focusing our attention on the mutual funds industry, for instance, this aspect can be of some concern: the minimum investment required, in some cases, is USD 50.000 or 100.000 or even 200.000. Some experts criticize this threshold, arguing that the funds should constitute an instrument accessible to all investors who want to invest their money in line with their religious beliefs.

Furthermore, the country allocation can represent a critical aspect of the management; to ensure liquidity and diversification, many Islamic funds invest in big corporations (incorporated in Japan or Western countries) but it is necessary to reconcile this portfolio necessity with the moral duty to achieve benefit for the Ummah (Moore, 1997) and to support Islamic companies. This point has no easy solution; as seen earlier, Islamic stock markets are not so capitalised as to absorb all the investments from mutual funds and allow an efficient diversification.

Together with these fund management issues, to definitely entering the financial markets mainstream, Islamic funds have to invest on policy, disclosure and conflict of interest avoidance.

According to Smyth (2006), since first funds were traditionally devoted to high net worth individuals and institutional investors, on-shore regulation was unimportant and most Islamic funds were registered on off-shore markets. Today, being registered on on-shore markets, such as the European or US markets, would be useful to allow retail investors to access Islamic mutual funds. The issue of monitoring and disclosure is directly connected to legal protections for small investors. From time to time, researchers have shown a general lack of transparency in the disclosure of Net Asset Value (NAV), management guidelines, and asset allocation. Still, most of Islamic mutual funds are, at present, incorporated in Arab jurisdictions like Bahrain, Saudi Arabia, Kuwait, and the economic figures are not gathered in the financial databases of conventional data providers (COX, 2002).

As for the conflict of interest, it is related to the shortage of Islamic scholars. As Yakuby (2006) stated, there are "too many banks and a few Islamic scholars". Given that there are less than ten eminent Shari'ah experts, each on must sit on dozens of boards, and this is, undoubtedly, a problem for competition and conflict of interest. 
Summing up, for Islamic mutual funds to compete in the global arena and to convince the sceptical investors, it is important to ensure transparency. This, perhaps, will be attainable in the very near future; a recent legislative framework issued in Dubai will, in fact, allow operators to establish funds in the on-shore Dubai International Financial Centre (DIFC) whose regulatory framework is modelled on the on-shore laws and practices of leading financial centres like New York, London and Hong Kong (Blair and Aliga, 2006).

\section{Review of the literature}

Since accepting a responsibility other than maximising profits may impose a burden on returns, as emphatically argued by the Nobel laureate Milton Friedman (1970 and 1987), many researchers, beginning in the $80 \mathrm{~s}$, have focused their research interest on SRI performance, and, in the following decades, on Islamic funds. From a portfolio theory point of view, as soon as we restrict the menu of assets available, we are likely to endanger the performance of the portfolio due to a lack of diversification. For this reason, most researchers have tried to determine whether SRI funds perform worse than common funds because of less diversification and/or sector exclusion. This same idea has been applied to Islamic portfolios.

The link between financial investments and ethical concerns was first analysed by Grossman and Sharpe (1986) in response to the so-called "South Africa divestment". In their paper, they compared a universe comprising all NYSE stocks with a South Africa-Free (SAF) universe, including only NYSE stocks not shown on the "black lists". The two universes were completely different in terms of size. The divested SAF universe consisted of companies whose market capitalisation was significantly smaller than those of the total universe. The findings regarding the performance and size of the two portfolios were very interesting; over a period from 1959 to the end of 1983, the SAF portfolio would have outperformed the NYSE. The SAF portfolio tracked the NYSE closely while achieving its higher return. Having identified this relatively better performance, they analysed the determinants of historical performance. Analysis of the factors contributing to the SAF portfolio's return indicated that the exclusion of South Africa-related stocks hurt portfolio performance while the small stock bias of the SAF strategy greatly increased portfolio return.

Luther, Matatko and Corner (1992) focused their analysis on British ethical funds, investigating their performance and the potential size effect associated with performance. In their research they found no clear evidence of over/under performance relative to benchmark indices. They verified, instead, clear evidence of a small firm bias in the portfolio. The results of Mallin et al. (1995) show that the ethical trusts tended to outperform the non-ethical trusts. In Gregory et al. (1997), the ethical funds were skewed toward small firms and, additionally, the small firm effect played an important role in explaining time series and cross-sectional returns of UK unit trusts.

On the other side of the ocean, Hamilton et al. (1993) found evidence that the market did not price social responsibility characteristics. Socially responsible mutual funds did not earn statistically significant excess return and the performance of such mutual funds was not statistically different from the performance of conventional mutual funds.

In a recent paper, Bauer et al. (2004) focused on performance and investment style using an international database containing 103 ethical mutual funds (32 from the UK, 16 from Germany and 55 from the US). Using a Carhart multifactor model to compare ethical and conventional funds, they found no evidence of significant differences in risk-adjusted performance.

Empirical evidence suggests that SRI funds and conventional funds have a similar performance in terms of financial returns. From a statistical point of view, the differences in performances, when they exist, are not significant. In spite of different techniques used by different authors, the results indicate that the hypothesis of SRI funds underperformance due to a lack of diversification can be rejected; however, SRI funds do not add value in terms of performance. As for Islamic funds, there 
is not yet a rich literature documenting their behaviour and performance; most of the research is based on Shari'ah indices ${ }^{7}$ and shows mixed results. According to Elfakhani and Hassan (2005) and Hussein (2005), the behaviour of Islamic mutual funds does not differ from that of conventional funds. The simple explanation for these similar performances stems from the number of stocks that belong to the portfolios: the minimum threshold needed to eliminate specific and diversifiable risks is guaranteed for both the SR and Islamic investment context.

Hakim and Rashidian (2004), however, focus on indices, and find that the application of Islamic filters creates an Islamic index that has a peculiar risk and return profile that is not affected by the market as a whole.

This paper tries to unify the studies regarding SRI and their performance with the available studies on Islamic investments. As seen, some authors have analysed the characteristics of Islamic indices, comparing them to the conventional indices but not with the SR counterparts. To the best of the authors' knowledge, this is the first time that SRI and Islamic indices are analysed and compared.

\section{The Sharpe's analysis: style, sector and country allocation}

Our empirical analysis concentrates on the major relevant indices for the European market. Applying a standard Sharpe's analysis (Sharpe, 1992), the primary objective is to test the impact of socially responsible, as well as faith-based Islamic screens on the management style and on the sector and country composition of the most popular SR and Islamic indices.

The exercise is not intended to reveal statistically significant differences in long-run performance. Indeed, as discussed previously, the contraction in the universe of eligible assets doesn't show a relevant impact on performance. A deep investigation on the style, sector and country composition of the indices can provide, instead, a useful starting point to assess whether SRI and Islamic Funds (IF) are to be considered viable alternative investments.

We focus on five relevant European indices, including three sustainability indexes (the DJ Sustainability Europe, the DJ Sustainability Europe ex AGTF and the FTSE4 Good Europe), one Islamic index (FTSE Islamic Europe) and a general conventional index (FTSE Developed Europe).

\section{[ Insert Table 2 about here ]}

The first part of Table 2 offers some interesting insight regarding the investment style of the portfolios under analysis. We have used the Dow Jones Total Market STOXX indices, TMI Value and Growth, to track the behaviour of our portfolios. Over the period shown, the sustainable indices are slightly more growth than value, but the difference is negligible: FTSE Developed Europe, with a $51 \%$ value vs. $49 \%$ growth is equally distributed. FTSE Islamic, instead, signals a strong preference for growth stocks - the value style accounts for only $30 \%$ of the portfolio. This preference possibly reflects the exclusion of Financials (which are generally "value" stocks) from the Islamic compliant portfolios, signalling, on the other side, a possible overweight on sectors that have behaved as "growth" over the period considered. This includes, for instance, industrials, consumer goods, health care, and consumer services.

In terms of size, Islamic stock selection does not neglect the "small" stocks, differently from the general behaviour of the sustainable indices. The FTSE Developed shows, instead, a more balanced approach in terms of size composition of the portfolio.

When we regress the index's performance on a combination of style (growth/value) and size (small/medium/large), we derive the general composition of our portfolios. The Islamic portfolio is 
mainly a Large Cap Growth (66\%) portfolio with a sensible weight posed on Small Cap Value $(13 \%)$ and Large Cap Value (20\%). The emphasis posed on the Large Cap Growth portion of the portfolio distinguishes the FTSE Islamic from both the sustainability counterparts and the general conventional index.

The middle part of Table 2, showing the sector allocation, allows us the opportunity to confirm the intuition about the inclusion/exclusion of some sectors we hinted at, when analysing the value/growth composition. Also in this case, we have used the DJ STOXX sector indices to track the behaviour of our portfolios.

In the FTSE Islamic, as foreseeable, Financials (including Banks, Insurance, Financial Services and Real Estate) show a zero weight. The sustainability indexes, instead, are strongly invested in Financials (16-18\% in Banks, $8 \%$ in Insurances).

Investments in Oil\&Gas show substantial differences: the FTSE Islamic is invested in this sector in a percentage that is almost double that of the remaining indexes (25\% vs. 11-13\%). Again, this is not surprising; Islamic countries are primary producers of oil and the investment in these companies is both permissible and suggested, since it favors the economic betterment of the Ummah. Sustainability indexes, instead, apply some filters on these companies; being a polluting sector, only those companies acting as sustainability leaders can be included in the portfolios.

Although the Islamic portfolios skew heavily toward Oil\&Gas, this is not enough to counterbalance the zero weight on Financials; indeed, on average, other sectors such as Food and Beverage, Retail, Personal and House Goods show higher values when compared to the sustainability indexes.

Some more interesting insights stem from the third part of Table 2, where we focus on the country allocation of European portfolios. In this case we have used the MSCI country indices to track the behaviour of our portfolios. If we focus on the percentage invested in the German stock market, we can immediately identify a substantial difference in the composition of the indices under analysis. The FTSE Islamic completely neglects the German market, and this behaviour is consistent if we perform a robustness check on different time horizons.

This result looks only apparently "odd", indeed a closer analysis of the sector allocation can clarify the exclusion. As has been shown, Financials are zero weighted in the Islamic portfolios. This means that Banks, Insurance and Financial Services (including Real Estate activities) are screened out from the portfolios. If we proxy the German market with the DAX 30 index, we can easily see that 8 out of 30 stocks (as of 30 May 2007) are immediately screened out after a qualitative sector assessment: Allianz, Commerzbank, Deutsche Bank, Deutsche Borse, Deutsche Postbank, Hypo Real Estate, Muench Rueckvers (financial companies), and Tui (part of the oftenpenalized Travel and Leisure sector). The Italian MIB30 is also characterized by a sizable presence (both in terms of capitalisation and in number of stocks) of banks and insurance, but, at the same time, there are a number of stocks that are generally favoured in Islamic investment (e.g., Telecom, Media, Energy, Personal Goods). This could explain why the Italian market is overrepresented on the Islamic index. This same line of reasoning can be applied when explaining the preference for Nordic countries' markets, where industrials, consumers' discretionary and information technology are well represented.

The differing compositions in terms of style, sectors and countries, as discussed, could signal potential divergence in the behaviours of these indices, although, as indicated in previous studies, no differences can be detected in the long run from a performance point of view. We then concentrate our attention on the trends in the price series of the stock indices. 


\section{The Vector Autoregressive Model}

We test the divergence hypothesis using appropriate econometric techniques, going beyond a simple correlation analysis. For robustness reasons, we turn our attention to daily time series, with a sample ranging from June 2000 to the end of April 2007 (1,803 observations). The analysis is limited to FTSE indices and excludes the Dow Jones; we do this to control for the potential bias introduced by different index methodologies.

The FTSE4 Good and FTSE Islamic represent, again, the proxies for screened portfolios in a socially responsible and Islamic sense. The universe from which both restricted indices select their stocks is the FTSE Developed Europe Index. The test investigates whether there exists cointegration between sustainability, Islamic and global index, as well as with interest rates, proxied by Euribor $3 \mathrm{~m}$.

We first check the results of a standard unit root test (Augmented Dickey Fuller). ${ }^{8}$ For the four series, our results clearly reject the null hypothesis of unit root in the differences, but not in the price levels.

We then turn our attention to their links over time. The traditional approach is based on correlation of returns among the series. However, this approach cannot identify a stable relation. In addition, high levels of correlation can be spurious. The correlation is strongly linked to the sample selected, and neglects to consider the link in the stochastic trends.

We rely, instead, on the theory of cointegration, discussed in Engle and Granger (1987) and use the testing procedure developed by Johansen and Juselius (1990). We investigate the cointegration relations between the four series in an overall model, as in couples.

It is natural to question whether linear transformations, other than differencing, will also induce stationarity. The answer is not obvious; in fact, unlike differencing, there is no guarantee that the outcome must be stationary $(\mathrm{I}(0))$. Cointegration analysis is designed to find linear combinations of variables that also remove unit roots.

In a bivariate context, if $y_{t}$ and $x_{t}$ are both non-stationary in levels (I(1)), there may (but need not) be a unique value $\alpha$, such that $y_{t}-\alpha x_{t}$ is $\mathrm{I}(0)$. In other words, there is no unit root in the relation linking $y_{t}$ and $x_{t}$. Consequently, cointegration is a restriction on a dynamic model, and so is testable. Cointegration vectors are of considerable interest when they exist, since they determine I(0) relations that hold between variables which are individually non-stationary. Such relations are often called "long-run equilibria", since it can be proven that they act as "attractors" towards which convergence occurs, whenever there are departures from these long-run values.

I(1) variables "wander" (often quite widely) because of their stochastic trends, whereas (weakly) stationary variables have constant means and variances; if there exists a linear combination that delivers an I(0) relation, one might think that it can be clearly detected from graphs of the variables. Unfortunately, in general, these graphs are not straight interpretable.

Thus, cointegration may or may not exist among variables that do or do not "look cointegrated"; the only way to find out is through careful statistical analysis, rather than relying on visual inspection. These two points, namely the importance, but the non-obvious nature, of cointegrated relations motivates our analysis.

Here, we will focus on a vector autoregression (VAR) as a description of the system to be investigated.

Consider the generic p-dimensional vector autoregressive model:

$$
X_{t}=\prod_{1} X_{t-1}+\cdots+\prod_{k} X_{t-k}+\Phi D_{t}+\varepsilon_{t},
$$


as our point of origin, where $\varepsilon_{t}$ are assumed to be independent and Gaussian distributed error terms.

The variable $D_{t}$ contains deterministic terms such as a constant, ${ }^{9}$ a linear trend and seasonal dummies. The error correction form for the model is

$$
\Delta X_{t}=\prod X_{t-1}+\sum_{i=1}^{k-1} \Gamma_{i} \Delta X_{t-i}+\Phi D_{t}+\varepsilon_{t},
$$

and it is well known that if the characteristic polynomial has all its roots outside the unit-disk, then $X_{t}$ is stationary. If the polynomial has one or more unit roots, then $X_{t}$ is an integrated process. A unit root implies that $\Pi$ has reduced rank $r<p$, and if the number of unit roots equals $p-r$, then the process $X_{t}$ is integrated of order one. When $\Pi$ has reduced rank, it can be written as a product of two $p \times r$ matrices, $\Pi=\alpha \beta^{\prime}$ of rank r, such that the model can be expressed in the form

$$
\Delta X_{t}=\alpha \beta^{\prime} X_{t-1}+\sum_{i=1}^{k-1} \Gamma_{i} \Delta X_{t-i}+\Phi D_{t}+\varepsilon_{t}
$$

This process can be inverted to an infinite moving average representation, also known as the Granger representation. It should now be evident that a cointegrated VAR provides a rich model. Indeed, the representation shows:

- the matrix $\beta$ (cointegration vectors) with the property that $\beta^{\prime} X_{t-1}$ is a stable process that defines an equilibrium relationship between the variables in $X_{t}$;

- the adjustment matrix $\alpha$ describes the reaction of the system to last period's disequilibrium $\beta^{\prime} X_{t-1}$

- the coefficients of the term $\Delta X_{t-i}$, representing short-term changes resulting from previous changes in the market, which need not have permanent effects on the levels.

For example, if the rank of the matrix $\operatorname{rank}(\Pi)=0$, then no series of the variables can be expressed as a linear combination of the remaining series. This indicates that no long-run relationship exists among the series in the VAR model; as a test of cointegration, a rank of 0 means integration is rejected.

On the other hand, if the rank is 1 , or greater than 1 , then there exists one or more cointegrating vectors. This indicates a long-run relationship, or that the series exhibits significant evidence of behaving as a cointegrated system.

In a multivariate test of cointegration, we are interested in whether there exists at least one cointegrating vector. In other words, whether the rank of the coefficient matrix $\Pi$ is at least 1 . Thus, if the rank of the matrix is greater than or equal to 1 , the null of no cointegration will be rejected. We apply a likelihood ratio test: ${ }^{10}$ the null hypothesis is that the number of cointegrating vectors is $\mathrm{r}$, versus the alternative $r=p$. This alternative corresponds to the case where none of the series has a unit root and thus a stationary VAR may be specified in terms of the levels of all the series. The test is also repeated for $r=0,1, \ldots, p-1$. 
The results of cointegration tests may be sensitive to the lag structure chosen. The proper lag profile for the $\operatorname{VAR}(\mathrm{p})$ model may be determined using model selection criteria. The general approach is to fit VAR(p) models with orders $p=0, \ldots, p_{\max }$, and choose the value of $\mathrm{p}$ which minimizes some model selection criteria. The two most common information criteria are the Akaike Information Criterion (AIC) and Schwarz-Bayesian Information Criterion (BIC). The two information criteria in our analysis suggest considering 6 lags, or trading days.

Another relevant aspect that influences the test is the specification of the model in terms of constant and trend assumptions. Because we tested our variables for unit roots having rejected the hypothesis of (trend-) stationarity in favour of unit roots, we exclude a linear trend in the cointegration equation $\left(\alpha \beta^{\prime} X_{t-1}\right)$. The choice of a constant term in the cointegration equation is more appropriate; approximations usually introduce some constant term, for example due to the use of raw interest rates, or because of different units of measurement resulting from the stock indices' building methodology. For these motivations we thus chose to include an intercept in the cointegration equation, but not in the VAR, ${ }^{11}$ as our preferred model. ${ }^{12}$

\section{[ Insert Table 3 about here ]}

The results shown in Table 3 are not surprising. The full cointegration system reveals at least two possible vectors of cointegration. We also estimated cointegration systems based on the variables in couples (first considering any index with the Euribor 3m, and then between the tree stock indices).

First of all, all the three indices under analysis are cointegrated with interest rates. This is not surprising for the FTSE Developed and the FTSE4 Good; indeed, their investment philosophy, is related to the market as a whole, and the market behaviour is influenced by interest rates.

As foreseeable, notwithstanding the exclusion of stocks fundamentally related to interest rates, such as Financials, and the exclusion of all those stocks with a balance-sheet deeply influenced by interest rates, also FTSE Islamic is influenced by trends in interest rates. Our data, thus, exhibit a cointegration between FTSE Islamic and Euribor $3 \mathrm{~m}$. When we look at the pair cointegration, we see that FTSE4 Good and FTSE Developed are cointegrated, but we cannot reject the null of no cointegration when we pair the Islamic index with FTSE Developed and FTSE4 Good.

In the first case, the explanation derives directly from the methodology by which FTSE Developed and FTSE4 Good are built. The latter index derives directly from FTSE Developed after applying SR filters; apart from the exclusion of a few sectors, the general philosophy is related to a best-in-class screening that allows the asset manager to choose corporations that intend to become corporate sustainability leaders (see Table 1). So, the two indices, though different, have a common root.

The second finding, related to FTSE Islamic vs. FTSE Developed and FTSE4 Good, is quite interesting - FTSE Islamic is not cointegrated with the SR and the conventional index. The exhibits show that the Islamic index possesses a stochastic trend that is not comparable with either of the other two indices. Since our market data indicate that SRI portfolios and Islamic portfolios exhibit different behaviour, this can represent a valuable insight toward answering our research question, about the closeness of econometric profile. Furthermore, this could be of interest for an investor seeking to build diversified portfolio.

Similarly, we find that the application of Islamic filters creates an Islamic index with a peculiar econometric profile that is not affected by the market as a whole, but is, as usual for a stock index , cointegrated with the interest rates. 


\section{Faith-based investments as ethical or SRI: some remarks}

The first socially responsible funds had a religious basis and were, at first, defined as "ethical funds". In religious terms, the word ethic (deriving from the ancient Greek word "ethos", meaning "habit, use") identifies a strictly defined set of behavioural norms. In the first investors' idea, in the $60 \mathrm{~s}$, the term "ethical" was a synonym of "religious".

In the following decades, scholars tended to abandon the "ethical" definition, replacing it with a more general idea of "social responsibility" and linking it to some good cause worthy of being pursued. For this reason, socially responsible funds are perceived as "different" from the conventional ones and whenever the concerned investors judge that their personal values are consistent with the underlying philosophy of the SR fund, they decide to concentrate on a screened universe of stocks (Benson et al., 2006).

The critical point related to this reasoning is not simply one class of SR fund; each fund is free to focus on the points that the promoter judges to be of the highest importance and to reflect those values in exclusion or inclusion screens. In financial markets, then, all funds that include "nonfinancial" management criteria can be generically defined as socially responsible. This "rule of thumb" can lead to the existence, in the SR category, of funds that are completely different in terms of composition, and which can pursue values that are mutually inconsistent (Dunfee, 2003). Addressing this point, Sparkes (2001) wonders, "whose ethics, which investment?"

Elgari (2002) includes Islamic funds in the family of "ethical funds", stating that the basic concept of Islamic investments derives from ethical investments, as is the case with the Pax World Fund. DeLorenzo (2002) goes further in his reasoning: according to Shari'ah, he states, business must be "responsible" and "committed" to good causes. Unifying the ideas expressed by these two eminent experts, it would seem a natural extension to include the Islamic funds in the SR family.

Furthermore, the general aims of Islamic economic rules and socially responsible funds are very similar. In both cases, the betterment of the whole society represents the ultimate purpose; in the Islamic world, this cannot be reached without a strict compliance to all Shari'ah prescriptions. In the case of socially responsible funds, the ultimate goal is a sustainable economic system that takes into account social and environmental effects. The final result of the two approaches is, strictu sensu, the same.

Dunfee (2003) proposes a generic and broad definition of social investing, including any investment strategy that takes into account non-financial criteria with a social dimension. This would allow us to include faith-based investments in the SR family. However, this definition is rather generic, and is open to several criticisms since it includes criteria that can be antithetical.

Thus, the inclusion of the faith-based Islamic funds in the SR family is not straightforward. To clarify these points, we propose a comparison table that summarize what we have said about the modus operandi of a SR fund and a generic Shari'ah compliant fund.

\section{[ Insert Table 4 about here ]}

From a close analysis of the table, it is evident that there may be some contradictions between Islamic and socially responsible funds. The first substantial inconsistency is in the regarding the filters that are imposed. Through best-in-class strategy, SR funds are allowed to consider "borderline" companies or sectors; this represents a beneficial addition to the fund diversification strategy. There are no specific financial ratios to be considered or restrictions posed on fund management activities, such as margin trading and short sale or the use of derivatives. The ethical committee, when present, has a consulting role without any sort of veto power. 
In the Shari'ah funds, by contrast, some sectors, such as conventional banks and insurance companies, are to be excluded entirely. Asset managers are requested to strictly adhere to financial ratios, and the settlement of these criteria is determined by the Shari'ah board, whose decisions are binding for the manager.

In addition, we should mention an essential point related to behaviours regarding human rights and environmental screens. In the case of Islamic funds, the application of some of the SR screens can lead to a potential conflict of interest. Some of the "countries of concern" that are on the watch list for human rights violations are Islamic countries. When applied, such negative screens would oblige Islamic asset managers to exclude countries like Syria, Egypt, Iran, and Saudi Arabia. In Islamic terms, this is a contradiction or even nonsense; these countries belong to the Ummah and should be, therefore, favoured. Furthermore, in managing Shari'ah funds, no attention is paid to environmental issues, which can lead to the inclusion of stocks that, in a SR context, would be screened out for their negative impact on environment. This is particularly evident in the sector allocation. As seen in Table 2, the portfolios are markedly different due to the exclusion, in the Islamic case, of Financials, and overrepresentation in Oil\&Gas that, being a high polluting sector, is instead carefully managed in the SR portfolios and often penalised.

Moreover, one important insight is related to the emphasis on performance. In the socially responsible case, the basic goal is twofold and takes into account the profit-seeking process: first, being socially responsible "pays" because socially responsible companies are managed so as to minimize legal and environmental issues in the future, and thus the SRI does not jeopardize the profit. Second, from a social point of view, the responsibility represents a moral duty to take care of the future generations.

As a general result in the SR case (and in accordance with the triple bottom line - People, Planet, Profit), the social and environmental screens are as important as the financial ones (and this explains why, at a certain point in their life, SR managers introduced the best-in-class strategy). Generalizing, we could say that an "SR fund archetype" is characterized by the equal emphasis placed on the attainment of the three P's.

In the Islamic management, however, there are two layers of importance. The first layer includes all the religious screens and the second layer refers to the research of a positive risk/return profile. The attainment of a positive return is, of course, of fundamental importance, but is secondary to the religious screens.

Some of the potential inconsistencies between faith-based investments and SR ones are, of course, not confined to Shari'ah investments and the result can be generalised. We could mention, for example, AveMaria mutual fund investment policies; this portfolio includes companies that do not violate the core teachings of the Catholic Church. In applying the negative criteria, the fund manager excludes all companies that offer non-marital partner benefits to their employees. This screen could clash with some SR funds promoting non-discriminatory practices toward, for instance, employees with different familiar habits.

Many faith-based funds (Mennonite, Lutherans, Catholic, Islamic, Methodist, just to mention the most prominent) exist in the financial marketplace, and they can apply a wide range of different screens. Religious groups place their investments in line with their views and those views could be expressed in mutually inconsistent portfolios. One company could be included or excluded according to the values underlying the fund management.

These universes (religious and SR) could converge if shareholder advocacy methods were largely used. According to Valpey (2002) and Usmani (2002), in the Islamic investments a moral duty exists to promote Shari'ah compliant business practices; using the means of shareholder advocacy could become more and more important, as has been the case in the US. If extensively used, this strategy could lead to more similar portfolios, and the exclusion criteria would become less important. 
Some asset managers consider SR and Islamic funds as two different investment classes; very recently, Dow Jones and Sam Group launched Dow Jones Islamic Market Sustainability, a bridge between Islamic and SR funds. The index represents companies that are compatible with Islamic investment guidelines, while at the same time are determined to be corporate sustainability leaders. Explaining the genesis of this new index, the SAM executives state that they have repeatedly received inquiries from asset managers who want to combine Islamic investment principles with a thorough selection of leading companies in terms of economic, environmental and social criteria (Dow Jones and SAM Group, 2006). According to these asset managers, then, SR companies and Shari'ah compliant ones belong to different asset classes.

Our quantitative analysis confirms this: although cointegrated with interest rates, FTSE Islamic shows different and unique characteristics as compared to conventional FTSE Developed Europe and the SR FTSE4 Good. The results shown suggest that, when comparing Islamic portfolios with general SR portfolios, we are looking at two different classes of investments. The same is valid for FTSE Islamic vs. a conventional index (e.g., FTSE Developed Europe).

\section{Conclusions}

Summing up, we have verified through both qualitative and quantitative methods that Islamic funds show different characteristics when compared to SRI, both in terms of asset allocation and econometric profile. Faith-based funds are managed in accordance with specific, clearly defined values, and these values can clash with the emphasis an SR fund places on human rights and environmental protection. Moreover, the results deriving from our quantitative and econometric analysis show that we are dealing with two different portfolios, not only in terms of country and sector exposure, but also in terms of the econometric trends that characterize each portfolio.

Rebus sic stantibus, it could be useful to define norm-based funds (as Catholic, Islamic, Lutherans or Methodist) as "religious funds" or "faith-based funds", in order to underscore their religious basis and to give investors a clear understanding of the values that characterize the modus operandi of each fund and its potential risk and return profile. These classes of religious investments are, of course, similar to SRI, but have unique, intrinsic characteristics that are easily distinguishable. This indicates an urgent need to determine a set of shared and transparent guidelines for managing SRI, tied for instance, to some universally acknowledged strategies for screening investments. 


\section{References}

AAOIFI: 2005, "Accounting, Auditing \& Governance Standards (for Islamic Financial Institutions), English version", Manama.

Abbasi, S., K. Hollman and J. Murray: 1989, "Islamic Economics: Foundations and Practices", International Journal of Social Economics 16(5), 5-17.

Ahmed, T.E.: 2002, “Accounting Issues for Islamic banks”, in S. Archer and R.A. Karim (eds.), "Islamic Finance, Innovation and Growth", Euromoney books and AAOIFI (London).

Al-Amine, M. and M. Al-Bashir: 2001, "The Islamic Bonds Market: Possibilities and Challenges", International Journal of Islamic Financial Services 3(1), 1-18.

Archer, S. and R.A. Karim: 2002, "Introduction to Islamic Finance", in S. Archer and R.A. Karim (eds.), Islamic Finance, Innovation and Growth, Euromoney books and AAOIFI (London).

Avanzi Sri Research, "Green Social and Ethical Funds in Europe, 2006 Review", available on www.avanzi-sri.org.

Baldwin, D.: 1990, “Turkey: Islamic Banking in a Secularist Context”, in R. Wilson (ed.), Islamic Financial Markets (Routledge, New York), pp. 33-58.

Bakar, M.: 2002, "The Shari'ah supervisory board and issue of Shari'ah ruling and their harmonisation in Islamic banking and finance", in S. Archer and R.A. Karim (eds.), Islamic Finance, Innovation and Growth, Euromoney books and AAOIFI (London).

Bauer, R., K. Koedijk and R. Otten: 2005, "International Evidence on Ethical Mutual Fund Performance and Investment Style", Journal of Banking and Finance 29, 1751-1767.

Benson, K. T. Brailsford and J. Humphrey: 2006, "Do Socially Responsible Fund Managers Really Invest Differently?”, Journal of Business Ethics, 65(4), 337-357.

Blair, M. and D. Aliga: 2006, "A New Framework for Collective Investment Funds in the Middle East”, Journal of International Banking Law and Regulation, 21(8), 440-448.

Bruntland Commission: 1987, Our Common Future, (Oxford University Press), Oxford.

Chapra, U.M.: 1985a, Towards a Just Monetary System (The Islamic Foundation, Leicester).

Chapra, U.M.: 1985b, "Commentary on M.M. Metwally: Role of a Stock Exchange in an Islamic Economy”, Journal of Research in Islamic Economics (Winter), 75-81.

Cooper, C. and B. Schlegelmilch: 1993 , "Key Issues in Ethical Investment”, Business Ethics: a European Review 2(4), 213-227.

Cox, S.: 2002, "Retail and private client services", in S. Archer and R.A. Karim (eds.), Islamic Finance, Innovation and Growth, Euromoney books and AAOIFI (London).

Cowton, C.: 1994, "The Development of Ethical Investment Products", in A.R. Prindl and B. Prodhan (eds.), Ethical Conflict in Finance (Blackwell, Oxford).

Delorenzo, T.Y.: 2002, “The Religious Foundations of Islamic Finance”, in S. Archer and R.A. Karim (eds.), Islamic Finance, Innovation and Growth, Euromoney books and AAOIFI (London).

Dickey, D.A. and W.A. Fuller: 1979, "Distribution of the Estimators for Autoregressive Time Series with a Unit Root", Journal of American Statistical Association, 74, 427-431.

Dow Jones: 2006, "Guide to the Dow Jones Islamic Market Index", available on www.djindexes.com.

Dow Jones and Sam Group: 2006, "Dow Jones and SAM Group Launch New Dow Jones Islamic Market Sustainability Index", Dow Jones press release. 
Dunfee, T.W.: 2003, "Social Investing: Mainstream or Backwater?", Journal of Business Ethics 43, 247-252.

Elefakhani, S. and M.K. Hassan: 2005, "Performance of Islamic Mutual Funds", $12^{\text {th }}$ ERF Conference Paper.

Elgari, M.: 2002, "Islamic Equity Investment", in S. Archer and R.A. Karim (eds.), Islamic Finance, Innovation and Growth, Euromoney books and AAOIFI (London).

Engle, R. and C. Granger: 1987, "Cointegration and Error Correction: Representation, Estimation and Testing", Econometrica 55(2), 251-276.

EUROSIF: 2006, “European SRI Study, 2006”, available on www.eurosif.org.

Fadeel, M.N.: 2002, "Legal Aspects of Islamic Finance", in S. Archer and R.A. Karim (eds.), Islamic Finance, Innovation and Growth, Euromoney books and AAOIFI (London).

Failaka, : 2007, "Islamic Funds Report 2006: A comprehensive Review of Islamic Equity Funds", April, Failaka, Chicago.

Friedman, M.: 1962, Capitalism and Freedom, (University of Chicago Press, Chicago).

Friedman, M.: 1970, "The Social Responsibility of Business is to Increase its Profits", New York Times Magazine, reprinted in Donaldson, T. and Werhane, P.: 1983, "Ethical Issues in Business: A Philosophical Approach", (2nd Edition, Englewood Cliffs, NJ: Prentice Hall).

FTSE: 2001, "Ground Rules for the Management of FTSE Global Islamic Index Series", available on www.ftse.com.

FTSE: 2006, "FTSE4Good Index Series: Inclusion Criteria".

Girard, E. and M.K. Hassan: 2005, "Faith-Based Ethical Investing: The Case of Dow Jones Islamic Indexes", FMA Papers.

Gregory, A. J. Matatko and R. Luther: 1997, "Ethical Unit Trust Financial Performance: Company Effects and Fund Size Effect", Journal of Business Finance and Accounting, 24(5), 705725.

Grossman, B. and W. Sharpe: 1986, "Financial Implications of South Africa Divestment", Financial Analysts Journal, 42(4), 15-31.

Hamilton, S. H. Jo and M. Statman: 1993, "Doing Well While Doing Good? The Investment Performance of Socially Responsible Mutual Funds", Financial Analysts Journal, 49(6), 62-66.

Hakim, S. and M. Rashidian: 2004, "Risk and Return of Islamic Stock Market Indexes", Paper Presented at the International Seminar of Nonbank Financial Institutions: Islamic Alternatives (Kuala Lumpur, Malaysia).

Hellsten, S. and C. Mallin: 2006, “Are 'Ethical' or 'Socially Responsible' Investments Socially Responsible?", Journal of Business Ethics 66, 393-406.

Husain, S.T.: 2002, "Project Finance", in S. Archer and R.A. Karim (eds.), Islamic Finance, Innovation and Growth, Euromoney books and AAOIFI (London).

Hussein, K.A.: 2005, “Islamic Investment: Evidence from Dow Jones and FTSE Indices", Paper Presented at the 6th International Conference on Islamic Banking and Finance (Jakarta, Indonesia), Nov. 14-21.

Johansen, S.: 1995, Likelihood-Based Inference in Cointegrated Vector Autoregressive Models, (Oxford University Press, Oxford). 
Johansen, S. and K. Juselius: 1990, "Maximum Likelihood Estimation and Inference on Cointegration-With Applications to the Demand for Money", Oxford Bulletin of Economics and Statistics 52(May), 169-210.

Kamali, M.H.: 1997, "Islamic Commercial Law: An Analysis of Options", The American Journal of Islamic Social Sciences 14, 17-39.

Luther, R. J. Matatko and D. Corner: 1992, "The Investment Performance of UK Ethical Unit Trust”, Accounting Auditing \& Accountability Journal 5(4), 57-70.

Mallin, C.A., B. Saadouni and R.J. Briston: 1995, "The Financial Performance of Ethical Investment Funds", Journal of Business Finance and Accounting, 22(4), 483-496.

Maroun, Y.: 2002, "Liquidity Management and Trade Financing”, in S. Archer and R.A. Karim (eds.), Islamic Finance, Innovation and Growth, Euromoney books and AAOIFI (London).

Mills, P. and J. Presley: 1999, Islamic Finance: Theory and Practice (MacMillan, New York).

Moore, P.: 1997, Islamic Finance, a Partnership for Growth (Euromoney Publications, London).

Naughton, S. and T. Naughton: 2000, "Religion, Ethics and Stock Trading: The Case of an Islamic Equities Market", Journal of Business Ethics 23 (2), 145-159.

Nyazee, I.: 1998, Islamic Law of Business Organisation: Corporations (Islamic Research Institute, Islamabad) .

Orlitzky, M., F. Schmidt and S. Lynes: 2003, "Corporate Social and Financial Performance: a Meta Analysis", Organization Studies 24(3), 403-441.

Saleh, N.: 1986, Unlawful Gain and Legitimate Profit in Islamic Law: Riba, Gharar and Islamic Banking, Cambridge Studies in Islamic Civilisation, Cambridge University Press.

Samuels, J.M. and N. Yacout: 1981, "Stock Exchanges in Developing Countries", Savings and Development 5(4), 217-232.

Sharpe, W.F.: 1992, “Asset Allocation: Management Style and Performance Measurement”, The Journal of Portfolio Management, 18(2), 7-19.

Smyth, M.: 2006, "Islamic Funds Come of Age", Middle East Banker, 11, 28-30.

Social Investment Forum: 2005, "2005 Report on Socially Responsible Investing Trends in the United States", available on www.socialinvest.org.

Sparkes, R.: 2002, Socially Responsible Investment, a Global Revolution (John Wiley and Sons, Chichester).

Sparkes, R.: 2001, “Ethical Investment: Whose Ethics, Which Investment?", Business Ethics: a European Review 10(3), 194-205.

Taylor, R.: 2001, "Putting Ethics into Investments", Business Ethics: a European Review 10(1), 53-60.

Usmani, M.: 2002, An Introduction to Islamic Finance (Kluwer Law International, The Hague).

Valpey, F.S.: 2002, "Structuring Islamic Equity Funds: Shari'ah Portfolio Management and Performance", Cambridge Massachusetts: Center for Middle Eastern Studies, Harvard University.

Wilson, R.: 1997, "Islamic Finance and Ethical Investment", International Journal of Social Economics 24(11), 1325-1342.

Wilson, R.: 2002, "The Evolution of the Islamic Financial System”, in S. Archer and R.A. Karim (eds.), Islamic Finance, Innovation and Growth, Euromoney books and AAOIFI (London). 
Yacuby, N.: 2006, “Too Many Islamic Banks, Few Islamic Scholars”, Shirkah 1(1).

Table 1. Most common strategies used in Europe

\begin{tabular}{|c|c|}
\hline STRATEGY & DEFINITION \\
\hline Ethical exclusions & $\begin{array}{l}\text { This refers to exclusions in which a large number of } \\
\text { negative criteria and/or filters are applied (as } \\
\text { opposed to just tobacco or weapons, for example). }\end{array}$ \\
\hline Positive screening & $\begin{array}{l}\text { Seeking to invest in companies with a commitment } \\
\text { to responsible business practices, or that produce } \\
\text { positive products and/or services. Includes Best-in- } \\
\text { class and Pioneer screening. }\end{array}$ \\
\hline Best-in-class & $\begin{array}{l}\text { Approach where the leading companies with regard } \\
\text { to SEE* criteria from each individual sector or } \\
\text { industry group are identified and included in the } \\
\text { portfolio. }\end{array}$ \\
\hline $\begin{array}{l}\text { Pioneer screening / } \\
\text { Thematic investment propositions }\end{array}$ & $\begin{array}{l}\text { Thematic funds, based on ESGa issues such as the } \\
\text { transition to sustainable development and a low } \\
\text { carbon economy. May focus on sectors such as } \\
\text { water, energy, etc. }\end{array}$ \\
\hline Norms-based screening & $\begin{array}{l}\text { Negative screening of companies according to their } \\
\text { compliance with international standards and norms } \\
\text { such as issued by OECD, ILO, UN, UNICEF, etc. }\end{array}$ \\
\hline $\begin{array}{l}\text { Simple screens / } \\
\text { Simple exclusions }\end{array}$ & $\begin{array}{l}\text { An approach that excludes a single given sector from } \\
\text { a fund (such as arms manufacture, publication of } \\
\text { pornography, tobacco, animal testing, etc.). Simple } \\
\text { screens also include human rights screens (such as } \\
\text { excluding Sudan or Myanmar) and Norms-based } \\
\text { screening. }\end{array}$ \\
\hline Engagement & $\begin{array}{l}\text { Engagement is applied by some fund managers to } \\
\text { encourage more responsible business practices } \\
\text { and/or enhance investment returns. It relies on the } \\
\text { influence of investors and the rights of ownership, } \\
\text { and mainly takes the form of dialogue between } \\
\text { investors and companies on issues of concern. } \\
\text { Engagement may extend to voting practices. }\end{array}$ \\
\hline Integration & $\begin{array}{l}\text { The explicit inclusion by asset managers of CG/ } \\
\text { bSEE-risk into traditional financial analysis. }\end{array}$ \\
\hline
\end{tabular}

${ }^{\mathrm{a}} \mathrm{ESG}$ stands for environmental, social and governance

${ }^{\mathrm{b}} \mathrm{SEE}$ stands for social, environmental and ethical.

Source: Eurosif (2006) 
Table 2. Sharpe's analysis: style, sector and country composition

\begin{tabular}{|c|c|c|c|c|c|}
\hline & $\begin{array}{l}\text { FTSE4GOO } \\
\text { D EUROPE }\end{array}$ & $\begin{array}{c}\text { DJ } \\
\text { SUSTAINAB } \\
\text { ILITY } \\
\text { EUROPE } \\
\end{array}$ & $\begin{array}{l}\text { DJ EX AGTF } \\
\text { EUROPE }\end{array}$ & $\begin{array}{c}\text { FTSE } \\
\text { ISLAMIC } \\
\text { EUROPE }\end{array}$ & $\begin{array}{l}\text { FTSE AW } \\
\text { DEVELOPE } \\
\text { D EUROPE }\end{array}$ \\
\hline Obs. \# (31/07/2000 - 31/08/2006) & 74 & 74 & 74 & 74 & 74 \\
\hline \multicolumn{6}{|c|}{ STYLE ANALYSIS } \\
\hline (Total Market Index)TMI Value & $45 \%$ & $48 \%$ & $47 \%$ & $30 \%$ & $51 \%$ \\
\hline TMI Growth & $55 \%$ & $52 \%$ & $53 \%$ & $70 \%$ & $49 \%$ \\
\hline (Tracking error) TE & $0,576 \%$ & $0,590 \%$ & $0,654 \%$ & $1,058 \%$ & $0,238 \%$ \\
\hline (R squared) R2 & $99 \%$ & $99 \%$ & $98 \%$ & $95 \%$ & $100 \%$ \\
\hline TMI Large & $94 \%$ & $100 \%$ & $100 \%$ & $91 \%$ & $79 \%$ \\
\hline TMI Mid & $6 \%$ & $0 \%$ & $0 \%$ & $0 \%$ & $21 \%$ \\
\hline TMI Small & $0 \%$ & $0 \%$ & $0 \%$ & $9 \%$ & $0 \%$ \\
\hline TE & $0,489 \%$ & $0,435 \%$ & $0,495 \%$ & $1,108 \%$ & $0,234 \%$ \\
\hline R2 & $99 \%$ & $99 \%$ & $99 \%$ & $94 \%$ & $100 \%$ \\
\hline Large Cap Value & $46 \%$ & $49 \%$ & $50 \%$ & $20 \%$ & $42 \%$ \\
\hline Mid Cap Value & $1 \%$ & $2 \%$ & $0 \%$ & $0 \%$ & $7 \%$ \\
\hline Small Cap Value & $0 \%$ & $0 \%$ & $0 \%$ & $13 \%$ & $3 \%$ \\
\hline Large Cap Growth & $46 \%$ & $48 \%$ & $48 \%$ & $66 \%$ & $38 \%$ \\
\hline Mid Cap Growth & $6 \%$ & $1 \%$ & $2 \%$ & $0 \%$ & $8 \%$ \\
\hline Small Cap Growth & $1 \%$ & $0 \%$ & $0 \%$ & $1 \%$ & $3 \%$ \\
\hline TE & $0,533 \%$ & $0,491 \%$ & $0,543 \%$ & $1,012 \%$ & $0,241 \%$ \\
\hline $\mathrm{R} 2$ & $99 \%$ & $99 \%$ & $99 \%$ & $95 \%$ & $100 \%$ \\
\hline \multicolumn{6}{|c|}{ SECTOR ALLOCATION } \\
\hline Aut\&Prt & $0 \%$ & $0 \%$ & $0 \%$ & $0 \%$ & $0 \%$ \\
\hline Banks & $18 \%$ & $18 \%$ & $20 \%$ & $0 \%$ & $16 \%$ \\
\hline Bas Res & $1 \%$ & $4 \%$ & $4 \%$ & $3 \%$ & $1 \%$ \\
\hline Chem & $9 \%$ & $8 \%$ & $8 \%$ & $3 \%$ & $9 \%$ \\
\hline Cns\&Mat & $0 \%$ & $4 \%$ & $5 \%$ & $4 \%$ & $4 \%$ \\
\hline Fd\&Bvr & $3 \%$ & $5 \%$ & $3 \%$ & $6 \%$ & $3 \%$ \\
\hline Fin Svcs & $6 \%$ & $0 \%$ & $0 \%$ & $0 \%$ & $6 \%$ \\
\hline Hea Care & $9 \%$ & $10 \%$ & $11 \%$ & $17 \%$ & $8 \%$ \\
\hline Indus Gd & $0 \%$ & $3 \%$ & $1 \%$ & $5 \%$ & $3 \%$ \\
\hline Insur & $8 \%$ & $7 \%$ & $8 \%$ & $0 \%$ & $3 \%$ \\
\hline Media & $2 \%$ & $1 \%$ & $1 \%$ & $4 \%$ & $2 \%$ \\
\hline Oil\&Gas & $13 \%$ & $12 \%$ & $12 \%$ & $25 \%$ & $11 \%$ \\
\hline Pr\&Ho Gd & $6 \%$ & $1 \%$ & $0 \%$ & $7 \%$ & $10 \%$ \\
\hline Retail & $1 \%$ & $0 \%$ & $0 \%$ & $0 \%$ & $2 \%$ \\
\hline Tech & $8 \%$ & $8 \%$ & $8 \%$ & $10 \%$ & $6 \%$ \\
\hline Telecom & $11 \%$ & $13 \%$ & $13 \%$ & $12 \%$ & $10 \%$ \\
\hline Trv\&Lsr & $0 \%$ & $0 \%$ & $0 \%$ & $0 \%$ & $0 \%$ \\
\hline Util & $6 \%$ & $7 \%$ & $7 \%$ & $3 \%$ & $5 \%$ \\
\hline$T E$ & $0,484 \%$ & $0,551 \%$ & $0,559 \%$ & $0,654 \%$ & $0,305 \%$ \\
\hline $\mathrm{R} 2$ & $99 \%$ & $99 \%$ & $99 \%$ & $98 \%$ & $100 \%$ \\
\hline
\end{tabular}




\begin{tabular}{|c|c|c|c|c|c|}
\hline \multicolumn{6}{|c|}{ *Sectors follow the ICB standards } \\
\hline MSCI AUSTRIA & $0 \%$ & $0 \%$ & $0 \%$ & $4 \%$ & $0 \%$ \\
\hline MSCI FRANCE & $12 \%$ & $8 \%$ & $8 \%$ & $16 \%$ & $16 \%$ \\
\hline MSCI GERMANY & $18 \%$ & $19 \%$ & $20 \%$ & $0 \%$ & $12 \%$ \\
\hline MSCI ITALY & $6 \%$ & $3 \%$ & $4 \%$ & $3 \%$ & $7 \%$ \\
\hline MSCI SPAIN & $0 \%$ & $5 \%$ & $5 \%$ & $0 \%$ & $6 \%$ \\
\hline MSCI SWITZERLAND & $7 \%$ & $16 \%$ & $15 \%$ & $17 \%$ & $13 \%$ \\
\hline MSCI UK & $44 \%$ & $41 \%$ & $39 \%$ & $39 \%$ & $33 \%$ \\
\hline MSCI BELGIUM & $5 \%$ & $0 \%$ & $1 \%$ & $0 \%$ & $2 \%$ \\
\hline MSCI DENMARK & $0 \%$ & $0 \%$ & $0 \%$ & $7 \%$ & $2 \%$ \\
\hline MSCI FINLAND & $4 \%$ & $5 \%$ & $5 \%$ & $6 \%$ & $2 \%$ \\
\hline MSCI NORWAY & $0 \%$ & $0 \%$ & $0 \%$ & $4 \%$ & $3 \%$ \\
\hline MSCI SWEDEN & $3 \%$ & $2 \%$ & $2 \%$ & $6 \%$ & $3 \%$ \\
\hline TE & $0,461 \%$ & $0,506 \%$ & $0,577 \%$ & $0,748 \%$ & $0,230 \%$ \\
\hline $\mathrm{R} 2$ & $99 \%$ & $99 \%$ & $99 \%$ & $97 \%$ & $100 \%$ \\
\hline
\end{tabular}

Note: The Table reports the results of a standard style analysis on five relevant European indices, including three sustainability indexes (the DJ Sustainability Europe, the DJ Sustainability Europe ex AGTF and the FTSE4 Good Europe), one Islamic index (FTSE Islamic Europe) and a general conventional index, proxy for the global European equity market (FTSE Developed Europe). The estimated exposures to style, sector and country factors refer to the period July 2000 through August 2006, involving monthly time series (74 observations). To determine the style and sector allocation we regress the indices on the appropriate Dow Jones STOXX Total Market Indices (TMI). The country composition instead, is obtained using the Morgan Stanley Capital International (MSCI) country indices as explanatory variables. The weights shown correspond to the average holdings over the corresponding sample period. The bottom rows of each section reports the R squared and the tracking error of the constrained regression. 
Table 3. Tests for cointegration

Period: 12/06/2000 - 30/04/2007, obs n. $=1796$,

Lags interval (in first differences): 1 to 6

\begin{tabular}{|c|c|c|}
\hline HO =Number of Cointegrating Vectors & Trace stats & CV (5\%) \\
\hline \multicolumn{3}{|c|}{ Cointegrating System: $\{$ FTSEIslamic, FTSE4GOOD, FTSEDevel., Euribor $3 m\}$} \\
\hline None* & 97,85934 & 54,07904 \\
\hline At most $1 *$ & 52,27756 & 35,19275 \\
\hline At most $2 *$ & 21,07771 & 20,26184 \\
\hline At most 3 & 6,496648 & 9,164546 \\
\hline \multicolumn{3}{|c|}{ Cointegrating System: $\{$ FTSEIslamic, Euribor $3 m\}$} \\
\hline None* & 48,31568 & 20,26184 \\
\hline At most 1 & 7,183698 & 9,164546 \\
\hline \multicolumn{3}{|c|}{ Cointegrating System: $\{$ FTSE $4 G O O D$, Euribor $3 m\}$} \\
\hline None* & 45,38563 & 20,26184 \\
\hline At most 1 & 6,095224 & 9,164546 \\
\hline \multicolumn{3}{|c|}{ Cointegrating System: $\{$ FTSEDevel., Euribor $3 m\}$} \\
\hline None* & 44,01816 & 20,26184 \\
\hline At most 1 & 5,677516 & 9,164546 \\
\hline \multicolumn{3}{|c|}{ Cointegrating System: \{FTSEIslamic, FTSEDevel.\} } \\
\hline None & 17,15440 & 20,26184 \\
\hline At most 1 & 0,652550 & 9,164546 \\
\hline \multicolumn{3}{|c|}{ Cointegrating System: $\{$ FFTSE4GOOD, FTSEDevel. $\}$} \\
\hline None* & 26,29465 & 20,26184 \\
\hline At most 1 & 7,601791 & 9,164546 \\
\hline \multicolumn{3}{|c|}{ Cointegrating System: $\{$ FTSEIslamic, FTSE4GOOD $\}$} \\
\hline None & 18,75476 & 20,26184 \\
\hline At most 1 & 1,160726 & 9,164546 \\
\hline
\end{tabular}

Note: The Table shows the results of a standard cointegration test on tree European stock indices (FTSE Islamic Europe, FTSE4 Good Europe and FTSE Developed Europe proxing respectively an Islamic, SR and a conventional equity portfolio) and on interest rates for the Euro area proxied by Euribor $3 \mathrm{~m}$. The daily time series refer to the period June 2000 through April 2007 (1802 observations). The tests apply to 7 different cointegrating systems (VAR specifications), starting from a full system including all the four series, and than considering the 6 combinations of the series in couples. In each estimated VAR we included 6 lags (in first differences) for the variables involved, following the results of a preliminary specification test. The characteristics of the series, and the economic meaning of the model lead us to include an intercept in the error correction but not in the VAR section of the cointegrating systems.

* denotes rejection of the null hypothesis at the $5 \%$ significance level. 
Table 4. Key characteristics of SR and Islamic funds

\begin{tabular}{|c|c|c|}
\hline & ISLAMIC FUNDS & SOCIALLY RESPONSIBLE FUNDS \\
\hline $\begin{array}{l}\text { Clear definition of action } \\
\text { limits }\end{array}$ & $\begin{array}{l}\text { Yes. The guide is the Qur'an, } \\
\text { integrated when possible by } \\
\text { legal interpretations }\end{array}$ & $\begin{array}{l}\text { No. A universally recognised definition of social } \\
\text { responsibility does not exist. This is also true of } \\
\text { SEE and ESG definitions }\end{array}$ \\
\hline Faith-based rules & Yes & No \\
\hline Supervisory committee & Yes, Shariah Supervisory board & $\begin{array}{c}\text { Not necessary; where present, it is called Ethical } \\
\text { Committee }\end{array}$ \\
\hline \multicolumn{3}{|l|}{ Management Strategy } \\
\hline - Sector exclusion & $\begin{array}{l}\text { Yes, sectors considered not } \\
\text { compliant to the Qur'an are } \\
\text { excluded }\end{array}$ & $\begin{array}{l}\text { Yes. Sectors not compliant with social and } \\
\text { environmental criteria are excluded }\end{array}$ \\
\hline - Best-in-class & $\begin{array}{l}\text { No. There is a general } \\
\text { distinction between admissible } \\
\text { and prohibited assets*. The } \\
\text { strategy is in-out }\end{array}$ & $\begin{array}{l}\text { Yes. Firms operating in sectors generally } \\
\text { forbidden can be included if they exhibit a } \\
\text { commitment to socially responsible principles }\end{array}$ \\
\hline $\begin{array}{l}\text { - Screens based on } \\
\text { environmental } \\
\text { filters }\end{array}$ & No & Yes \\
\hline $\begin{array}{l}\text { - Screens related to } \\
\text { the human rights }\end{array}$ & No & Yes \\
\hline $\begin{array}{l}\text { - Screens associated } \\
\text { with transparent } \\
\text { corporate practices }\end{array}$ & No & Yes, but not in all cases \\
\hline $\begin{array}{l}\text { - Shareholder } \\
\text { advocacy }\end{array}$ & $\begin{array}{l}\text { Shareholders are encouraged to } \\
\text { formally express a negative } \\
\text { opinion regarding certain } \\
\text { practices }\end{array}$ & Yes, mostly used in US and Canadian markets \\
\hline $\begin{array}{l}\text { Restriction on investment } \\
\text { management }\end{array}$ & $\begin{array}{l}\text { Yes; some financial instruments } \\
\text { (e.g., preferred stock) and } \\
\text { investment activities are } \\
\text { forbidden }\end{array}$ & No \\
\hline & Yes. Faith-based filters are & \\
\hline Financial Screens & $\begin{array}{l}\text { applied during the stock } \\
\text { selection process. The core } \\
\text { principles on which the filters } \\
\text { are based relate to leverage, } \\
\text { presence of interest-bearing } \\
\text { assets and liabilities, high level } \\
\text { of debt and credit. }\end{array}$ & $\begin{array}{l}\text { There are no financial parameters that determine } \\
\text { the inclusion of an asset in the SRI index. The } \\
\text { fund manager will decide which ratios or } \\
\text { financial characteristics are required to include a } \\
\text { stock in the managed portfolio. }\end{array}$ \\
\hline
\end{tabular}

\footnotetext{
*Some sectors may be subject to interpretation
} 
${ }^{1}$ See, for instance, FTSE (2001 and 2006).

${ }^{2}$ For a general discussion about the Islamic financial system, see Wilson, 2002.

${ }^{3}$ See FTSE (2001) and Dow Jones (2006) for a discussion of the criteria used.

${ }_{5}^{4}$ For a discussion, see Usmani (2002).

${ }^{5}$ For a discussion, see also Samuels J.M. and Yacout N. (1981).

${ }^{6}$ For a discussion, see Moore, 1997 or Bakar, 2002.

${ }^{7}$ See also Girard and Hassan (2005).

${ }^{8}$ The results of the test are not reported but are available from the authors, at request.

${ }^{9} \mathrm{We}$ will discuss later the choice of intercept and trends for the model specification.

${ }^{10}$ The trace statistic reported in the Table 3 is computed as $L R_{w r}(r \mid p)=-T \sum_{i=r+1}^{p} \log \left(1-\lambda_{i}\right) \quad$ where $\lambda_{i}$ is the i-th largest eigenvalue of the $\Pi$ matrix.

${ }^{11}$ Introducing an intercept in the VAR, i.e., a constant in the first differences model, means that the non-stationary variables are $\mathrm{I}(1)$ and have a drift, which causes a tendency to continuously move in an upward or downward direction. This is not the case in our analysis involving stock indices and interest rates.

${ }^{12}$ If changes in the interest rate are on average zero, the hypothesis of a constant average growth rate (risk premium) of stock price indices, should lead to comparable levels for the tree indices self compensating in the cointegration vectors, than not requiring a separate constant in the VAR. Nevertheless, the cointegration results are robust to the alternative choice of intercept in the cointegrating equation as well as in the VAR component. 